\title{
MINING
}

UDC 622.271.3.

T. K. Issabek, Academ. of NAS of Republic of Kazakhstan, Dr. Sc. (Tech.), Prof., orcid.org/0000-0001-7718-933X,

A. Zh. Imashev, Cand. Sc. (Tech.), orcid.org/0000-0002-9799-8115,

N.B. Bakhtybayev, Cand. Sc. (Tech.), orcid.org/0000-0002-9816-9765,

Sh. B.Zeitinova, Cand. Sc. (Tech.), orcid.org/0000-0002-3489-8969
DOI: $10.29202 /$ nvngu/2019-2/3

Karaganda State Technical University, Karaganda, the Republic of Kazakhstan, e-mail: tyiak@mail.ru

\section{TO THE PROBLEM OF SELECTING VERTICAL SHAFTS LOCATION WITH COMBINED GEOTECHNOLOGY OF DEVELOPING DEPOSITS}

Purpose. Justification and development of scientific and methodological provisions and recommendations for determining the rational location of vertical shafts with the combined method of mining mineral deposits (the combined geotechnology), taking into account the new man-made impact factor: the open pit space, as well as contact of weakened rocks with the open pit, the presence of ground-based open pit facilities and communications) with approbation at the mine of the Zhairem MCC JSC (the Republic of Kazakhstan).

Methodology. When performing the studies on determining the location of vertical shafts in the combined geotechnology conditions (transition from open pit to the underground method), the calculation method of the geomechanical model of the massif according to P. S. Shpakov classification is used that allows using the numerical-analytical method to estimate stability of slopes for the open pit boards of arbitrary shape.

Findings. The algorithms for step-by-step, sequential, local optimization of qualitative characteristics and quantitative parameters for selecting the area of rational and safe location of vertical shafts and a model of the combined geotechnology using opening schemes of vertical shafts are proposed. The method for calculating and assessing stability of open pit slopes for open pit boards of arbitrary shape for the geomechanical model of a heterogeneous massif for 4 types of computational schemes is considered. The results of scientific and experimental studies in the conditions of the Ushkatyn-3 deposit (the Republic of Kazakhstan) allowed determining the zones of rock displacement around the pit and establishing safe distances for vertical shafts from the edge of the pit.

Originality. Studies for determining the rational and safe location of vertical shafts with the combined geotechnology, taking into account new technological factors: open pit space, areas of weakened rocks contacting the open pit, land-based open pit facilities, communications, and others. The model which allows determining the vertical shafts location in the combined geotechnology is developed. There are extended methodological provisions for calculating and assessing stability of the pit slopes for the geomechanical model of the heterogeneous massif which allow establishing the zones of the rock displacements and collapse on the earth surface.

Practical value. The proposed methodological guidelines and recommendations for selecting the rational place for laying vertical shafts, a model of the combined geotechnology when opening with vertical shafts, the ways of solving specific engineering and geomechanical tasks will improve the efficiency of using the combined geotechnology in the course of further development of fields that assume open-underground mining.

Keywords: ore deposits, combined geotechnology, vertical shafts, stability of slopes, geomechanical model

Introduction. The widespread use of the so-called combined geotechnology in the world is due to the fact that when developing fields with a changeable depth in wide ranges, the situation arises inevitably when, due to the economic inexpediency of this method, it becomes necessary to transit to the underground additional min-

(C) Issabek T. K., Imashev A. Zh., Bakhtybayev N.B., Zeitinova Sh. B., 2019 ing of the reserves. With increasing the depth of open pit mining, the amount of overburden increases dramatically and open pit mining becomes unprofitable due to implementation of a significant amount of mining and preparatory work [1]. For this reason, for example, in Kazakhstan, a number of large ore deposits (Nurkazgan, Kentobe, Sayak, Akzhal, Ushkatyn-3, and others) began moving from the open method to the underground min- 
ing of minerals, that is, to introduce the open-underground combined method. The reverse situation is also possible, when the development begins with the underground method and ends with the open one [2]. There can also be simultaneously used two methods.

In the transition from the open to the underground method of development, various difficulties arise with the opening and carrying out of mine workings in the underground part of the field, which requires deep scientific and experimental research to determine the rational and safe location of vertical shafts with calculating their stability positions of sophisticated geomechanics, this will ultimately affect the efficiency and quality of the technological processes of open-pit mining and consistency of the work of the entire transport and ventilation network of the deposit on the whole [3, 4].

Specifying a problem to be solved. With the combined geotechnology there are many specific engineering and geomechanical problems that significantly affect the efficiency of its use depending on the accuracy and quality of the decision.

With increasing the depth of mining operations, the solution of geomechanical problems that affect the issue of selecting a place for laying mine shafts and calculating their stability under conditions of an unspecified geomechanical state of the massif, which occurs under the effect of both underground and open-pit mining, becomes an important scientific-technical task affecting further development of the process of mining the entire field. The existing methods for determining the factors affecting selecting and justifying the location and calculating stability of vertical workings can hardly provide a reliable result due to the fact that the binding of workings has been carried out to the conditions of the underground excavation of still virgin massif.

In the world practice, in most cases, when transiting to the combined geotechnology, the underground part of the field is opened up by vertical shafts. One of the most important tasks that ensure the effectiveness of the combined geotechnology is the correct selection of the system for opening under-career (local) reserves and determining the rational and safe location of the main opening workings (vertical shafts). The solution of this problem is the purpose of these studies.

Analysis of the recent research. In order to study the problem associated with selecting the rational location of vertical shafts in the combined geotechnology there were studied works of many well-known Russian and foreign scientists [4]. There were considered well-known methods for determining the place of laying shafts in underground mining by L. D. Shevyakov [5], P. K. Sobolevsky [6]. The studies of M. Khudey, S. Vujnic and M. Radosavljević were also considered. These works dealt with selecting the location of the vertical shaft of the Velenje mine (Slovenia) using the multi-model analysis. They opted for the following programs that were widely used: PROMETHEE, ELECTRE, AHP and VIKOR [7]. Attention is paid to the works by researchers Qing Yu, Jinrong Ma, Hideki Shimada, Takashi Sasaoka who provide a numerical analysis of the mining model effect on stability of the shaft [8].
Unsolved aspects of the problem. At present a sufficiently large number of works are known on selecting the location of vertical shafts in underground mining. But there is no most appropriate methodology and justification of this problem for the specific features of the combined geotechnology. It is known that with the underground method, selecting the methods for opening, determining the location of the main opening workings is carried out taking into account various natural and technical factors [9]. However, for the combined geotechnology to these listed factors there are added new anthropogenic factors of influence: open pit space, areas of weakened rocks contacting the open pit, earlier erected ground-based open pit objects and communications, and others. In these circumstances selecting the location of the vertical shafts should be made taking into account the possibility of the most complete mining of both nearpit and under-pit reserves. With the combined geotechnology it is very important to ensure that the vertical shafts are located outside the area of occurrence of mineral resources at some distance from the risk-sensitive open pit zone of weakened rocks, with the condition that vertical shafts remain safe and in working condition throughout the entire period of their functioning.

Objectives of the article. The purpose of the study is substantiation and development of scientific and methodological foundations and recommendations for determining the rational location of vertical shafts when transiting to the combined geotechnology of development taking into account new man-made factors: open pit space, areas of weakened rocks contacting the open pit, the existence of earlier erected ground open pit facilities, communications, and others.

Presentation of the main research. In the practice of underground mining, the location of vertical shafts is usually selected across the strike or along the strike of the deposit depending on various natural and technical factors. In the first approach the shafts to ensure longterm functioning and durability during the entire service time until the completion of mining operations should be located outside the zone of weakened rocks.

Errors in determining the location of the shaft in the direction across the strike of the reservoir are fraught with serious negative consequences. Over time, during the development of the field from a certain depth, the process of rock loosening begins, and the shaft that is unacceptably close to the ore deposit, may undergo dangerous deformations and leave the state of work before the due date. The situation may lead to the need of driving another shaft. Its construction will entail huge unforeseen capital expenditures. If we opt for leaving a security pillar around the shaft, then this will lead to the loss of significant amounts of mineral resources for a considerable period.

It is known that the shafts are most advantageous to be placed in the bottom wall of the reservoir. With such an arrangement, top-level capital quarters, while acquiring the shortest length, accelerate the time for opening and commissioning new reserves significantly.

The task of selecting the methods for opening, the type of opening workings, parameters, as well as the 
places of their rational formation is complex. With the combined geotechnology there are many specific engineering and geomechanical problems that affect the effectiveness of its successful application.

These tasks essentially constitute the scientific and methodological basis for solving the scientific and technical problem of selecting the rational place for laying vertical shafts in the combined geotechnology. Based on the analysis of engineering-technical and geomechanical tasks when selecting the rational location of vertical shafts in the combined geotechnology, the following logical sequence of solving these problems is recommended:

- selecting the system of opening deposits and the type of opening workings taking into account specifics of the combined geotechnology;

- determining the sizes of zones of weak rock contacting the open pit extending from the surface of the earth to the final depth of the open pit. This evaluates the correctness of determining the rational location of vertical shafts;

- specifying the maximum depth of the pit, when the contour stripping factor is equal to the magnitude of the boundary stripping factor;

- assessing stability of the open pit slopes, rock deformations at the sides, stress values and their distribution along the pit contour under the combined geotechnology;

- carrying out a complex of engineering-geological surveys based on the visual study and instrumental measurements of the terrain, the build-up of the surface, the availability of transport routes (railways, highways), geological disturbances, aquifers, and others, in order to assess and to establish the area of safe location of vertical trunks.

The algorithms of step-by-step, sequential, local optimization of qualitative characteristics and quantitative parameters for selecting the area of safe location of ver- tical shafts and the model of the combined geotechnology when opening subcarrier reserves by vertical shafts are shown in Fig. 1.

With the combined geotechnology for determining the area of possible location of the shafts on the surface of the earth it is important to establish the boundaries of the sliding rocks along the contour of the pit. It is important to know the mechanisms and patterns of their formation, methods for determining and assessing stability of slopes, ledges, their impact on the process of collapse (sliding) of rocks along the contour of the pit, and others.

In view of the need to transit to the combined geotechnology in the conditions of the Ushkatyn-3 field (the Republic of Kazakhstan), representatives of Karaganda State Technical University (KSTU) carried out scientific and experimental studies to justify the magnitude of the shaft distance (the shaft location) during transition to underground mining. The purpose of the study was to determine a safe zone behind which it is advisable to have a vertical shaft for the subsequent underground mining of the field. To this end, the work was carried out in the southern and northern parts of the Ushkatyn-3 open pit to calculate stability of the slopes and sides of the open pit, which resulted in determining the distance between the vertical shaft and the open pit. The methodology is described below [10].

Fig. 2 shows a principal diagram for calculating stability of real open pit slopes.

When carrying out scientific research, the methodology for calculating the geomechanical model of the heterogeneous massif according to the classification by P.S. Shpakov was used, which is intended to assess stability of the open pit slopes in complicated geological conditions [10].

In the course of the work there were analyzed 4 types of computational schemes for assessing stability of the slopes composed of various types of rocks [10].

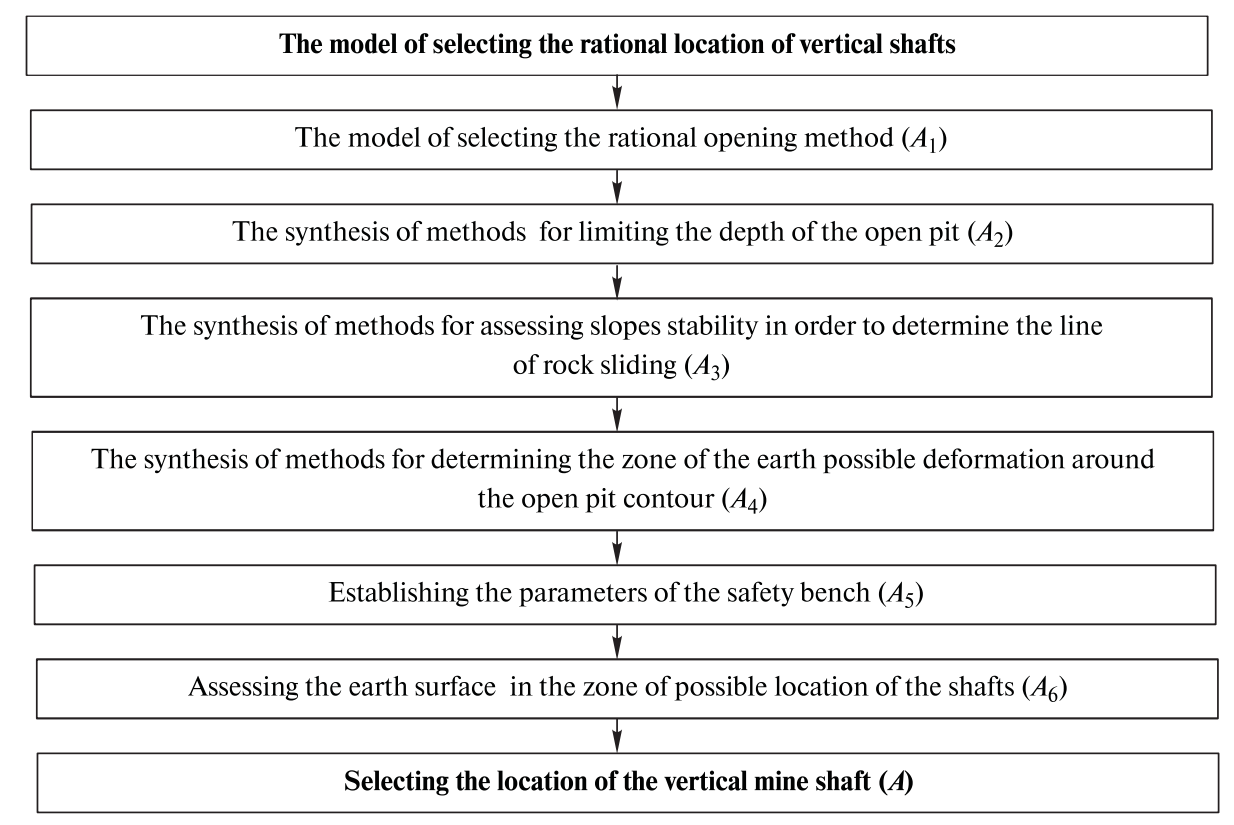

Fig. 1. Algorithm of successive local optimization of the process of selecting the vertical shaft location 


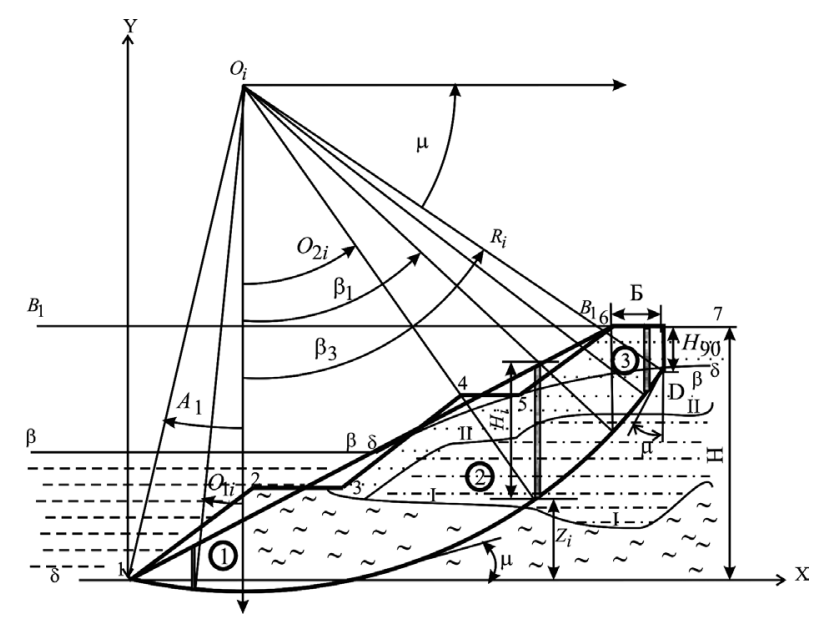

Fig. 2. Principal diagram of calculating a geomechanical model of the irregular massif

Scheme I is used for both homogeneous and multilayer open pit slopes, with dry rocks, whose skeleton density $\rho_{d r}$ is equal

$$
\rho_{d r}=q_{1}\left(V_{1}+V_{2}\right)^{-1},
$$

where $q_{1}$ is the mass of the rock skeleton; $V_{1}$ is the volume of the rock skeleton; $V_{2}$ is the volume of pores in the rock.

Scheme II is used in case when the rock is in the state of natural humidity, the depression curve is absent, the rock density $r$ is determined from expression

$$
\rho=\left(q_{1}+q_{2}\right)\left(V_{1}+V_{2}\right)^{-1},
$$

where $q_{2}$ is the mass of water fully or partially filling the rock pores.

Scheme III is used, when the open pit slopes are under water (the depression curve coincides with the slope contour, Fig. 2), the rock density (the rock weight is reduced by the water force) is determined in the following way

$$
\rho^{B}=\left(\rho_{m}-1\right)\left(1-n_{0}\right),
$$

where $\rho_{m}$ is the rock mineral part density, $\rho_{m}=q_{1} / V_{1} ; n_{0}$ is the rock porosity, $n_{0}=1-\rho_{d r} / \rho_{m}$.

Scheme IV is used for assessing stability of the flooded slopes (the depression curve $1-2-3-\delta-\delta$ ) or the submerged slopes till the $\beta-\beta$ level (the depression curve), the rock density is determined above the depression curve from expression (1) or (2), and under it from expression (3).

In accordance with the above basic schemes, the design or real contour of the pit wall and the groundwater line are applied on the geological section across the erosion of the pit wall. The characteristic and description of the rocks between the layers, the water level, the sliding surface, and the pit wall contour are given by the tableset functions [10].

If the sliding surface is not predetermined in advance, then it is rebuilt according to other existing methods [11-13]. To do this in accordance with Fig. 2, the coordinate system $X O Y$ is selected with the origin in the lower edge of the slope. The characteristic focal points are marked on the section.
The coordinates of intermediate points are calculated by specially developed programs INTPOL and SPOSGST9 [12], in which the tabular given function $x_{i}, y_{i}$ in the $X O Y$ coordinate system is used to describe it by the "sliding" Lagrange interpolating polynomial (SIPL). The instructions for the use of these programs are given below.

The sliding surface is approximated (hereinafter, its location is specified by the method of successive approximations), for which the average calculated strength characteristics $k_{a c}, \operatorname{tg} \rho_{a c}, \gamma_{a c}$ are determined [13].

For schemes I, II the average characteristics are calculated as weighted average

$$
\begin{gathered}
k_{a c}=\sum_{i=1}^{N} k_{i} l_{i} / \sum_{i=1}^{N} l_{i} ; \\
\operatorname{tg} \rho_{a c}=\sum_{i=1}^{N} N_{i} \operatorname{tg} \rho_{i} / \sum_{i=1}^{N} N_{i} ; \\
\gamma_{a c}=\sum_{i=1}^{N} \sum_{j=1}^{m} V_{i, j} \gamma_{i, j} / \sum_{i=1}^{N} \sum_{j=1}^{m} V_{i, j},
\end{gathered}
$$

for schemes III, IV

$$
\begin{gathered}
k_{a c}=\left(\sum_{i=1}^{N_{1}} k_{i} l_{i}+\sum_{i=1}^{N_{2}} k_{i}^{s} l_{i}^{s}\right)\left(\sum_{i=1}^{N_{1}} l_{i}+\sum_{i=1}^{N_{2}} l_{i}^{s}\right)^{-1} ; \\
\operatorname{tg} \rho_{a c}=\left(\sum_{i=1}^{N_{1}} N_{i} \operatorname{tg} \rho_{i}+\sum_{i=1}^{N_{2}} N_{i}^{s} \operatorname{tg} \rho_{i}^{s}\right)\left(\sum_{i=1}^{N_{1}} N_{i}+\sum_{i=1}^{N_{2}} N_{i}^{s}\right)^{-1} ; \\
\gamma_{a c}=\frac{\left[\sum_{i=1}^{N}\left(\sum_{j=1}^{m_{1}} V_{i, j} \gamma_{i, j}+\sum_{j=1}^{m_{2}} V_{i, j}^{s} \gamma_{i, j}^{s}\right)\right]}{\sum_{i=1}^{N}\left(\sum_{j=1}^{m_{1}} V_{i, j}+\sum_{j=1}^{m_{2}} V_{i, j}^{s}\right)},
\end{gathered}
$$

where $k_{i}, \quad \rho_{i}, \quad$ are coherence and internal friction angle on the sliding surface $l_{i}$ in the natural and watersaturated states; $\gamma_{i, j}, \gamma_{i j}$ is the rock density in the $i^{\text {th }}$ block of the $j^{\text {th }}$ layer in the natural and water-saturated states; $l_{i}, \quad$ is the elementary length of the sliding in the natural and water-saturated states; $V_{i, j}, V_{i j}$ is the elementary volume of the $j^{\text {th }}$ layer in the $i^{\text {th }}$ block in the natural and water-saturated states; $N_{i}$, are normal forces from the action of the rock massif within the $i^{\text {th }}$ block in the natural and water-saturated states; $N$ is the number of blocks; $N_{i}, m_{i}$ is the number of blocks and layers in the block that are above $(i=1)$ and under $(i=2)$ the depression curve.

Then the stability factor is determined [12]. Taking into account the non-submerged slope, it is determined by the formula

$$
n=\sum_{i=1}^{N}\left[\left(N_{i}-\Phi_{i}\right) \operatorname{tg} \rho_{i}+k_{i} l_{i}\right] / \sum_{i=1}^{N} T_{i}
$$

where forces $N_{i}, T_{i}$ are calculated as the components of the rock weight within the block together with the water in it, and forces $\Phi_{i}$ perpendicular to the sliding curve are determined by the formula 


$$
\Phi_{i}=\gamma\left(H_{i}-Z_{i}\right) l_{i},
$$

where $H_{i}-Z_{i}$ is the piezometric height averaged along the $1_{\mathrm{i}}$ contour.

For the submerged slope in formula (7) there are introduced additional forces of hydrostatic pressure that are normal to the flooded surface and are drifted to the sliding surface along the line of their action $[2,3]$, i. e.

$$
n=\frac{\sum_{i=1}^{N}\left\{\left[P_{i} \cos e_{i}+P_{i}^{B} \cos \left(\alpha-e_{i}\right) \cos ^{-1} \alpha-\Phi_{i}\right] \operatorname{tg} \rho_{i}+k_{i} l_{i}\right\}}{\sum_{i=1}^{N}\left[P_{i} \sin e_{i}-P_{i}^{B} \sin \left(\alpha-e_{i}\right) \cos ^{-1} \alpha\right]},
$$

where is the weight of the "free" (lying above the slope line) water within the block.

It should be noted that the proposed algorithm takes into account such a moment when the angle of inclination of the slope ledge or side is equal to $90^{\circ}$.

The stability factor is calculated by the numericalanalytical method [14].

The algorithm for solving these problems involves calculating the parameters for limiting slope for any slope heights. To do this, you need to specify only the numbers of points for which the calculation should be made (for example, points 3 and 5). In this case the calculation will be carried out for two and one ledge. Then, for each of the heights, in the corresponding sequence, the sliding surface with the minimum stability factor is found using formula (7).

However, the solution obtained is not mathematically faithful, since, as it was noted above, the calculation using dependence (7) was not the ultimate prism of a possible collapse, but its real schema, which is not in general equilibrium.

To bring the calculated slope of the ledge to the ultimate equilibrium, weighted average values of adhesion $k_{a c}$, internal friction angle $\rho_{a c}$, determined for the corresponding sliding surfaces by formulas (1-6) are used. The method of successive approximations is used to find the limiting values of the weighted average strength characteristics $k_{a c}$ and $\rho_{i}$, as well as the corresponding averaged sliding surface values for the limiting state of the slope. The stability factor of the open pit wall of an arbitrary shape in complicated mining-geological and hydrogeological conditions is determined from the expression

$$
n=\frac{k_{a}}{k_{\ddot{a} . l}}=\frac{\operatorname{tg} \rho_{a}}{\operatorname{tg} \rho_{a . l}}=\frac{k_{i}}{k_{i . n}}=\frac{\operatorname{tg} \rho_{i}}{\operatorname{tg} \rho_{i .} .}
$$

Then, the calculated value of $\mathrm{n}$ is compared with the permissible value, which is regulated by regulatory documents, at this the condition $n>n_{n}$ must be observed. If this condition is not observed, the pit profile should be corrected.

Based on the above algorithm, the program SPOSGS35C [10, 12] was developed.

As a result of solving the problem on a computer, all the necessary information, the initial data for the calculation is printed.

The defined problem is solved for layers of any configuration.
The proposed method of the massif geomechanical model (non-uniform) takes into account the stepped profile of the pit, the heterogeneity (layer-stiffness) of the massif, and others.

With the development of ore bodies by the open method, especially steeply dipping, in the displacement trough there is formed a zone of weakened rocks (zone of collapse) and a zone of displacement of rocks (Fig. 3).

The dimensions of these zones increase with the deepening of mining.

Fig. 4 presents a situation where, as a result of undermining the slopes and ledges of an open pit (but not the shaft itself), the sliding line of rocks can change significantly its position, so that the vertical shaft can be in the risk zone of weakened rocks.
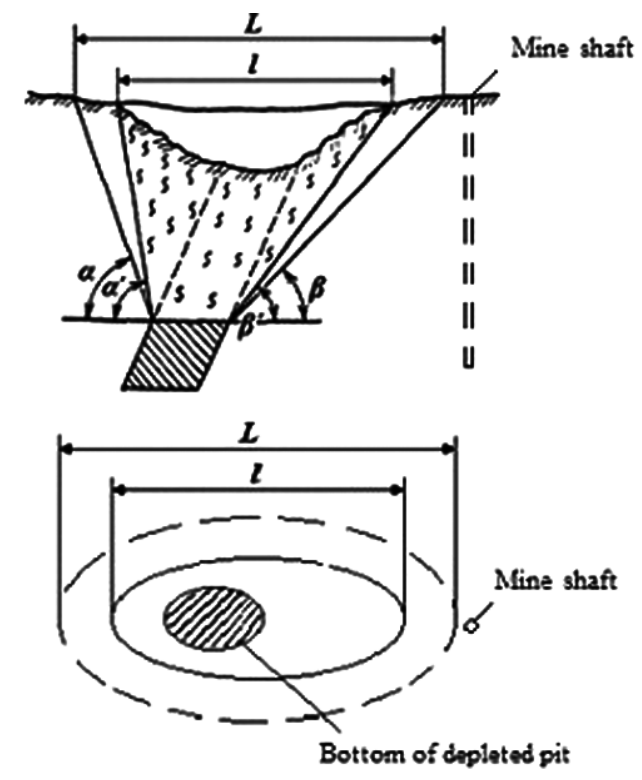

Fig. 3. Diagram of the rocks displacement with open mining:

$L$ - zone of rock displacements; $l$ - zone of rock collapse; $\alpha, \beta-$ angles of the rock displacement; $\alpha^{\prime}, \beta^{\prime}-$ angles of collapse

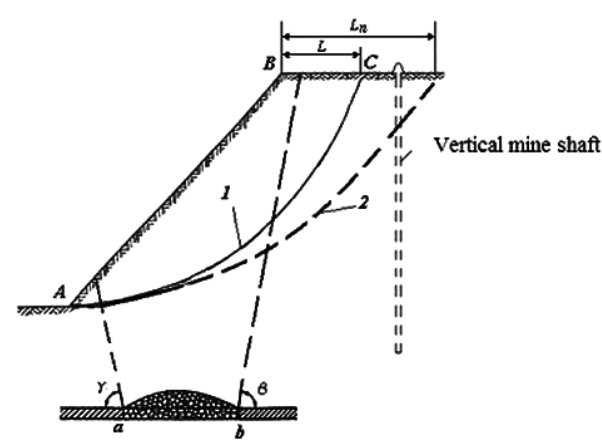

Fig. 4. Changing the position of the sliding line as a result of undermining slopes and ledges of an open pit:

1 - rock sliding line before undermining; 2 - sliding line after undermining; $L$ - distance from the edge ledge of an open pit to the boundary of the rock displacement on the earth surface before underground operations beginning; $L_{n}$ - the same as a result of undermining 
The degree of the rock softening as a result of development depends on specific conditions of the deposit. The massifs of rocky, rather elastic, medium-fractured rocks can reduce strength during undermining (in the displacement zone) by 1.5-2 times. There are a lot of reasons for weakening slopes of an open pit. Undermining significantly reduces the strength of the massif, leads to its decompaction. The mechanism of deforming slopes and board massifs points out that, other things being equal, the ratios of the horizontal components of the deformation vectors play the decisive role here [15].

Using the above techniques in the conditions of the Ushkatyn-3 deposit of the Zhairem MCC (the Republic of Kazakhstan), scientific and experimental works were carried out to determine the rational location of vertical shafts [16]. The weighted average value of the coefficient of rock strength on the scale of M. M. Protodyakonov for this field is $f_{a}=10$. Taking into account stratification of rocks, the following displacement angles are taken: $\delta=65 ; \beta=50 ; \beta_{1}=50$. For the southern and northern parts of the Ushkatyn-3 open pit, stability calculations were performed for the geomechanical model of a nonuniform pit slope as a result of which the shaft distance was established [12].

There were carried out studies to determine the location of the shaft by the condition of displacement of the rock massif. The calculation of stability of the rock massif was made by the known methods. All the methods take into account physical-and-mechanical properties of rocks and the depth of the development. The calculation was carried out through 5 sections characterizing the southern and northern part of the board of the Ushkatyn-III open pit.

Below there are the zones of displacement, rebuilt through sections $1-1 ; 2-2 ; 3-3 ; 4-4 ; 5-5$ [4] (Figs. 5-9).

By means of building the profile lines through $5 \mathrm{sec}-$ tions, the lines of rocks displacement zones were obtained. When determining the angles of displacement, the lines to the boundaries of the developed space are built in such a way that these lines or their continuation do not cross the developed space. The boundary angles, the angles of ruptures and the angles of collapse were determined without separating the stratum into sediments and bedrock at the points of the earth surface with deformations.

The angles defining the boundaries of the zones of the stoping influence on the vertical sections are shown in Fig. 2.

The following safe distances were established by the calculations: $180 ; 165 ; 115 ; 0 ;-100 \mathrm{~m}$.

Due to the connection of the points of displacement lines to the earth surface, there was finally obtained the region [17] within which the placement of a vertical shaft was not recommended (Fig. 10) [18].

Conclusions and recommendations for further research. In recent years the development of the mining industry in the world has been accompanied by the commissioning of new underground horizons for many of the existing mineral deposits, whose development initially began in the open way.

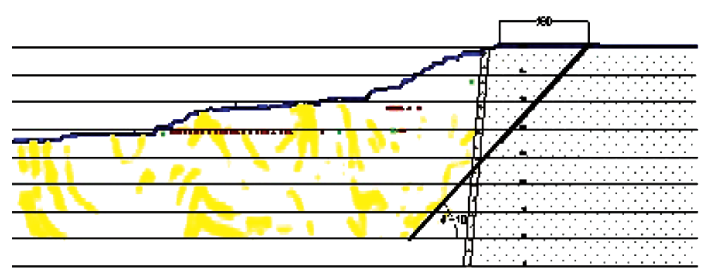

Fig. 5. Displacement zone through section 1-1

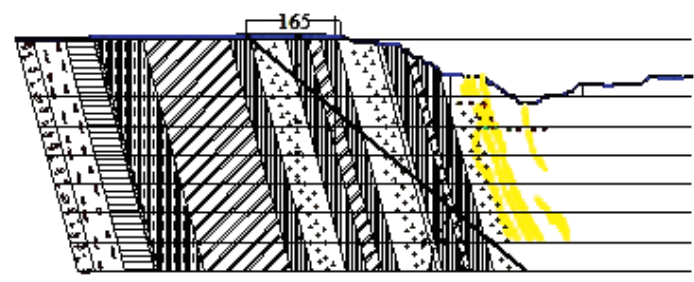

Fig. 6. Displacement zone through section 2-2

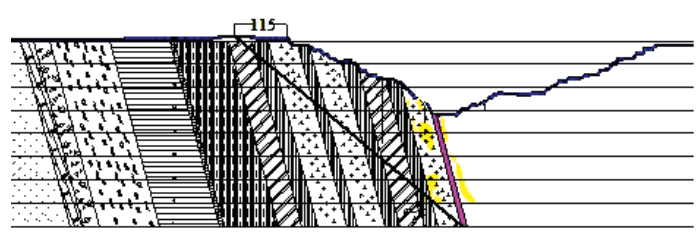

Fig. 7. Displacement zone through section 3-3

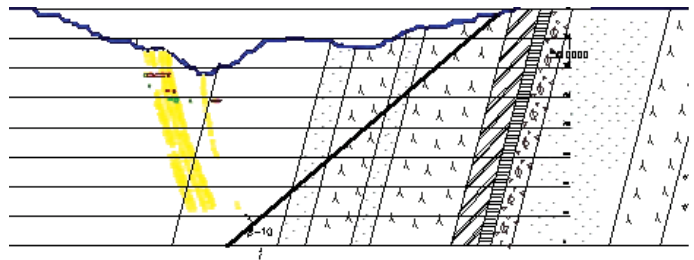

Fig. 8. Displacement zone through section 4-4

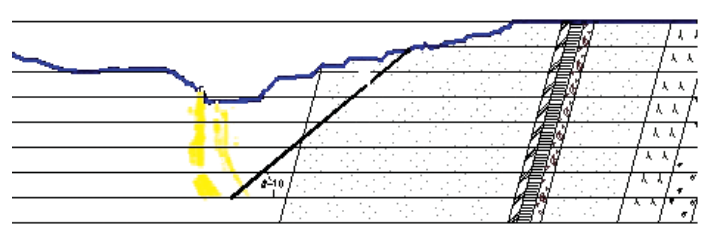

Fig. 9. Displacement zone through section 5-5

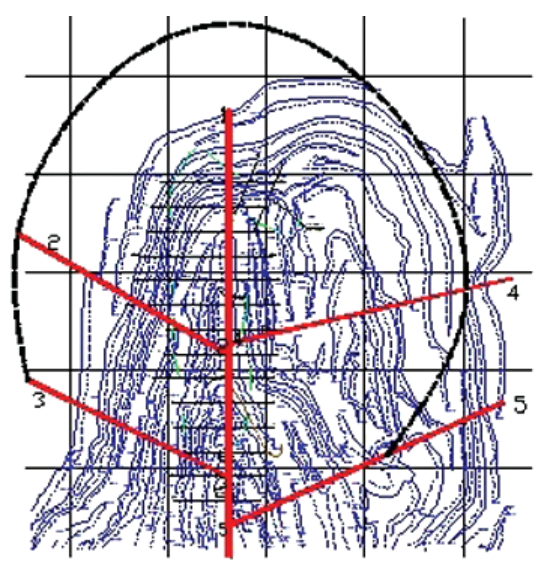

Fig. 10. Zone of the rock displacement in the north part of the Ushkatyn-3 mine 
With the combined (underground-open) method of mining mineral deposits the task of selecting the location of mine shafts and estimating the geomechanical state of the rock massif near them is an important and topical problem for both researchers and production workers. Further development and improvement of this problem will significantly improve the efficiency and scope of the advanced combined geotechnology not only in Kazakhstan but also in other mining countries.

\section{References.}

1. Volkov, Yu. V. and Sokolov, I. V., 2013. Underground geotechnology in the combined development of ore deposits. Gorny information and analytical bulletin (scientific and technical journal), 1, pp. 41-47.

2. Issabek, T.K., Baizbayev, M.B. and Abeuov, E.A., 2016. Combined development of ore deposits: Monograph. Karaganda: KSTU. ISBN 978-601-320-001-9.

3. Issabek, T.K., Takhanov, D. K., Imashev, A.Zh. and Zeytinova, Sh. B., 2018. Defining vertical sHaft location according то OS BABO (block stability in unit area) methodology. Mining Journal of Kazakhstan, 5, pp. 20-23. 4. Issabek, T. K., Zeytinova, Sh. B., Imashev, A. Zh. and Kuttybayev, A. E., 2018. Scientific approach to the definition of the location of the mine shaft. Mining Journal of Kazakhstan, 12, pp. 4-8.

5. Kaplunov, D. R. and Rylnikova, M. V., 2015. Designing the formation and development of mining systems with combined geotechnology. Gorny information-analytical bulletin (scientific and technical journal), 1, pp. 229-240.

6. Mitelman, A., Elmo, D. and Stead, D., 2018. Development of a spring analogue approach for the study of pillars and shafts. International journal of Mining Science and Technology, 28(2), pp. 267-274.

7. Hudej, M., Vujic, S., Radosavlevic, M. and Ilic, S., 2013. Multi-Variable Selection of the Main Mine Shaft Location. Physico-Technical Problems of Mining, 6, pp. 950-954.

8. Yu, Q., Ma, J. Shimada, H. and Sasaoka, T., 2014. Influence of Coal Extraction Operation on Shaft Lining Stability in Eastern Chinese Coal Mines. Geotechnical and Geological Engineering, 32(4), pp. 821-827.

9. Lobanova, T. V. and Trofimova, O. L., 2018. Up-todate geodynamic movements in the area of the mine shaft "sibiryak" of the Tashtagol mine. Problems of subsoil use, 3, pp. 70-80.

10. Shpakov, P. S. and Yunakov, Yu. L., 2017. Justification of parameters of sustainable dumps of Eldorado deposit. Mining Journal, 3, pp. 20-25.

11. Shpakov, P.S., Yunakov, Yu. L. and Rudenko, V. V., 2014. Research and substantiation of parameters of sustainable open pit slopes of the Eldorado deposit. Mining informational and analytical bulletin, 5, pp. 80-88.

12. Shpakov, P.S., Yunakov, Yu. L. and Rudenko, V. V., 2014. Calculation of Sustainability of Career Slopes of the Bogolyubovskoye Field. Mining informational and analytical bulletin, 4, pp. 185-190.

13. Ozhigin, D.S., Issabek, T. K. and Ozhigina, S. B., 2016. Monitoring of the state of stability of the sides and heaps of coal mines/Monograph. Germany: LAP LAMBERT Academic Publishing. ISBN 978-3-330-00812-0.
14. Wang, N., Wan, B. H., Zhang, P. and Du, X. L., 2015. Analysis on deformation development of openpit slope under the influence of underground mining. Legislation, Technology and Practice of Mine Land Reclamation. In: Proceedings of the Beijing International Symposium on Land Reclamation and Ecological Restoration (LRER 2014), Beijing, China. London: Taylor \& Francis Group, pp. 53-59. 15. Kainthola, A., Verma, D., Thareja, R. and Singh, T. N., 2013. A Review on Numerical Slope Stability Analysis. International Journal of Science, Engineering and Technology Research (IJSETR), 2(6), pp. 1315-1320. 16. Kozyrev, A., Fedotova, I. and Kasparyan, E., 2018. Management of geomechanical processes - the basis for selecting the optimal technologies for the development of mineral deposits. In: VII International Scientific Conference "Problems of Complex Development of Georesources" (PCDG 2018) [online], 56. Available at: <https://doi.org/10.1051/ e3sconf/20185602005> [Accessed 10 October 2018].

17. VNIPIgortsvetmet, 1988. Guidelines for observations of the displacement of rocks and the earth surface during underground mining of ore deposits [online]. Available at: $</$ biblioteka/cartochki/ 0059.htm> [Accessed 15 November 2017].

18. Guidelines on observations of the movement of rocks and the earth's surface during underground exploitation of ore deposits / Co-ordinated by order of the Committee on State Control of Emergency Situations and Industrial Safety of the Republic of Kazakhstan No. 39 of September 22, 2008 [online]. Available at: <https://online.zakon.kz/Document/?doc_ id=30517256 $>$ [Accessed 24 February 2018].

\section{До проблеми вибору місця розташування вертикальних стволів при комбінованій геотехнології відпрацювання родовищ}

\author{
Т. К. Ісабек, А. Ж. Імашев, Н. Б. Бахтибаєв, \\ ШІ. Б. Зейтінова
}

Карагандинський державний технічний університет, м. Караганда, Республіка Казахстан, e-mail: tyiak@mail.ru

Мета. Обгрунтування й розробка науково-методичних положень і рекомендацій щодо визначення раціонального місця закладення вертикальних шахтних стволів при комбінованому способі відпрацювання родовищ корисних копалин (комбінованої геотехнологіi) з урахуванням нового техногенного фактора впливу - відкритого кар'єрного простору, а також приконтактних до кар'єру ослаблених порід і наявності наземних кар'єрних споруд і комунікацій з апробацією на руднику АТ „Жайремський ГЗК“ (Республіка Казахстан).

Методика. При виконанні досліджень за визначенням місця закладення вертикальних шахтних стволів в умовах комбінованої геотехнології (переходу з відкритої розробки на підземний спосіб) використана методика розрахунку для геомеханічної моделі неоднорідного масиву за класифікацією П. С. Шпакова, що дозволяє із застосуванням чисельно-аналітичного методу оцінити стійкість кар'єрних укосів для бортів кар'єрів довільної форми. 
Результати. Запропоновані алгоритми поетапної, послідовної, локальної оптимізації якісних характеристик і кількісних параметрів вибору області раціонального й безпечного місця закладення вертикальних шахтних стволів і модель комбінованої геотехнології із застосуванням схем розкриття вертикальними стволами. Розглянута методика розрахунку та оцінки стійкості кар'єрних укосів для бортів кар'єрів довільної форми для геомеханічної моделі неоднорідного масиву для 4 видів розрахункових схем. Результати науково-експериментальних досліджень в умовах родовища „Ушкатин-3“ (Республіка Казахстан) дозволили визначити зони зрушення порід навколо кар'єру та встановити безпечні відстані закладення вертикальних стволів від краю кар'єру.

Наукова новизна. Проведені дослідження із визначення раціонального й безпечного місця закладення вертикальних шахтних стволів при комбінованій геотехнології з урахуванням нових техногенних факторів впливу: відкритого кар'єрного простору, приконтактних до кар'єру зон ослаблених порід, наземних кар'єрних об'єктів, комунікацій та ін. Розроблена модель дозволяє визначати місце розташування вертикальних стволів в умовах комбінованої геотехнології. Розширені методичні положення з розрахунку та оцінки стійкості кар'єрних укосів для геомеханічної моделі неоднорідного масиву, що дозволяють встановити зони зрушення та обвалення порід на земній поверхні.

Практична значимість. Запропоновані в роботі методичні положення й рекомендації щодо вибору раціонального місця закладення вертикальних шахтних стволів, модель комбінованої геотехнології при розтині вертикальними стволами, шляхи вирішення специфічних інженерних і геомеханічних задач дозволять підвищити ефективність застосування комбінованої геотехнології в ході подальшого освоєння родовищ, що припускає відкрито-підземну розробку.

Ключові слова: рудні родовища, комбінована геотехнологія, вертикальні стволи, стійкість укосів, геомеханічна модель

\section{К проблеме выбора местоположения вертикальных стволов при комбинированной геотехнологии отработки месторождений}

\section{Т. К. Исабек, А. Ж. Имашев, Н. Б. Бахтыбаев, ШІ. Б. Зейтинова}

Карагандинский государственный технический университет, г. Караганда, Республика Казахстан, e-mail: tyiak@ mail.ru

Цель. Обоснование и разработка научно-методических положений и рекомендаций по определению рационального места заложения вертикальных шахтных стволов при комбинированном способе отработки месторождений полезных ископаемых (комбинированной геотехнологии) с учетом нового техногенного фактора воздействия - открытого карьерного пространства, а также приконтактных к карьеру осла- бленных пород и наличия наземных карьерных сооружений и коммуникаций с апробацией на руднике $\mathrm{AO}$ „Жайремский ГОК“ (Республика Казахстан).

Методика. При выполнении исследований по определению места заложения вертикальных шахтных стволов в условиях комбинированной геотехнологии (перехода с открытой разработки на подземный способ) использована методика расчета для геомеханической модели массива по классификации П.С. Шпакова, которая позволяет с применением численно-аналитического способа оценить устойчивость откосов для бортов карьеров произвольной формы.

Результаты. Предложены алгоритмы поэтапной, последовательной, локальной оптимизации качественных характеристик и количественных параметров выбора области рационального и безопасного места заложения вертикальных шахтных стволов и модель комбинированной геотехнологии с применением схем вскрытия вертикальными стволами. Рассмотрена методика расчета и оценки устойчивости карьерных откосов для бортов карьеров произвольной формы для геомеханической модели неоднородного массива для 4 видов расчетных схем. Результаты научно-экспериментальных исследований в условиях месторождения „Ушкатын-3““ (Республика Казахстан) позволили определить зоны сдвижения пород вокруг карьера и установить безопасные расстояния заложения вертикальных стволов от края карьера.

Научная новизна. Проведены исследования по определению рационального и безопасного места заложения вертикальных шахтных стволов при комбинированной геотехнологии с учетом новых техногенных факторов воздействия: открытого карьерного пространства, приконтактных к карьеру зон ослабленных пород, наземных карьерных объектов, коммуникаций и др. Разработана модель, позволяющая определять местоположение вертикальных стволов в условиях комбинированной геотехнологии. Расширены методические положения по расчету и оценке устойчивости карьерных откосов для геомеханической модели неоднородного массива, позволяющие установить зоны сдвижения и обрушения пород на земной поверхности.

Практическая значимость. Предложенные в работе методические положения и рекомендации по выбору рационального места заложения вертикальных шахтных стволов, модель комбинированной геотехнологии при вскрытии вертикальными стволами, пути решения специфических инженерных и геомеханических задач позволят повысить эффективность применения комбинированной геотехнологии в ходе дальнейшего освоения месторождений, предполагающих открыто-подземную разработку.

Ключевые слова: рудные месторождения, комбинированная геотехнология, вертикальные стволы, устойчивость откосов, геомеханическая модель

Рекомендовано до публікаціі докт. техн. наук В.Н.Долгоносовим. Дата надходження рукопису 23.01.18. 